\title{
Al-Ummi Dalam Al-Qur'an: Studi Tafsir Tematik Terhadap Literasi Nabi Muhammad
}

\author{
Muhammad \\ UIN Maulana Malik Ibrahim Malang, Jl.Gajayana No 50 Dinoyo Lowokwaru Malang, E-mail: \\ muhammadlc@syariah.uin-malang.ac.id
}

\begin{abstract}
One of the mandatory nature of the prophet is intelligent. One sign of someone can be said to be intelligent when able to read-write. If the Prophet Muhammad was unable to read the writing, he lost one of his face traits. Scholars interpret the pronunciation of al-Ummi by not being able to read writing. When interpreted so can damage the prophetic reputation. This article discusses the intent of al-Ummi pronunciation in the Qur'an using qualitative method, using the Mudū'î interpretation approach, which is to compile the pronunciation of al-Ummi in the Qur'an, then recite one the pronunciation. Historically, rebuilding history has passed through the events of the corner as they were in the current space and time. Sociology, analyzing the truth from a social standpoint. By knowing the social conditions Arab Jahiliyah became a strong source of the presence or absence of write writing at the time. The results of the study show that writing was already running during the Jahiliyyah. All of Muhammad's uncle was able to read writing. None of the relevant pronunciation of al-Ummi is interpreted as unable to read writing, but al-Ummi's pronunciation in the Qur'an has a meaning of 1) Arabs. 2) People who have never listened to scripture readings.
\end{abstract}

Keywords: Al-Ummi, Thematic Tafsir, Literacy

\begin{abstract}
Abstrak
Salah satu sifat wajib nabi adalah cerdas. Salah satu tanda seseorang dapat dikatakan cerdas bila mampu baca-tulis. Jika Nabi Muhammad tidak mampu baca tulis, maka hilang salah satu sifat wajibnya. Ulama menafsirkan lafal alUmmi dengan tidak bisa baca tulis. Bila ditafsirkan demikian dapat merusak reputasi kenabian. Artikel ini membahas tentang maksud lafal al-Ummi yang ada dalam al-Qur'an dengan menggunakan metode kualitatif, menggunakan pendekatan tafsir $m u d u^{-} i$ yaitu menghimpun lafad al-Ummi yang ada dalam al-Qur'an, kemudian menfsirkan satu-persatu lafal tersebut. Historis, membangun ulang sejarah yang sudah lewat meninjau kejadian dari sudut sebagaimana yang ada pada ruang dan waktu saat itu. Sosiologi, menganalisis kebenaran dari sudut pandang sosial. Dengan mengetahui kodisi sosial Arab Jahiliyah menjadi sumber kuat akan ada atau tidaknya tulis menulis pada saat itu. Hasil penelitian menunjukkan bahwa tulis menulis merupakan hal yang sudah berjalan pada masa Jahiliyah. Semua paman Nabi Muhammad mampu baca tulis. Tidak ada satupun dari lafal al-Ummi yang relevan diartikan tidak
\end{abstract}


mampu baca tulis, akan tetapi lafal al-Ummi dalam al-Qur'an memiliki arti 1) orang Arab. 2) orang yang tidak pernah mendengarkan bacaan kitab suci.

Kata Kunci: al-Ummi, Tafsir Tematik, Literasi

\section{Pendahuluan}

Masa pra-terutusnya Nabi Muhammad sebagai seorang Nabi, dikenal sebagai masa Jahiliyah dan kaumnya pun diistilahkan dengan kaum Jahiliyah. Menurut keyakinan umat Islam dan tercatat dalam sejarah, istilah ini muncul disebabkan mereka tidak mengetahui baca tulis dan tidak memiliki etika. ${ }^{1}$ Lebih dari itu, baca-tulis terkenal hal yang cela dan tabu bagi orang-orang yang hidup pada masa Jahiliyah. ${ }^{2}$ Munculnya asumsi demikian, menimbulkan sebuah penilaian keawaman Nabi Muhammad dalam baca-tulis. Jika benar adanya orang-orang yang hidup pada masa Jahiliyah tidak bisa baca-tulis, maka tidak salah adanya anggapan bahwa Nabi Muhammad tidak bisa membaca dan menulis, sebab lingkungan pada saat itu buta huruf. Namun, keyaninan ini beda dengan penjelasan Eva Nugraha, ia menerangkan, tidak ada satupun lafal Jahiliyah yang ada dalam al-Qur'an selaras dengan arti buta huruf. ${ }^{3}$

Dengan demikian, argumen Nabi Muhammad tidak dapat baca-tulis dengan landasan hidup di masa Jahiliah tidak dapat dibenarkan. Jika dipaksakan, maka hal ini dapat merusak sifat wajib yang harus dimiliki oleh wajib seorang nabi dan rasul sebagaimana yang disepakati oleh para teolog Muslim baik klasik maupun modern. Sifat wajib itu ialah al-Shidq, al-Fathanah, al-Tabligh, dan al-Amanah. Jika membaca dan menulis merupakan sebuah kebutuhan yang tidak bisa lepas dalam kehidupan masa Jahiliyah sedangkan Nabi Muhammad tidak bisa membaca dan menulis, maka salah satu sifat wajib nabi dan rasul tidak dimiliki oleh Nabi Muhammad yang berupa al-Fathanah. Sedangkan hilangnya salah satu sifat wajib yang dimiliki oleh seorang nabi dan rasul dari diri Nabi Muhammad merupakan hal yang mustahil. ${ }^{4}$

Terdapat unsur pendorong lain yang menjadi penyebab munculnya argumen bahwa Nabi Muhammad tidak bisa baca tulis yaitu permulaan turunnya wahyu pada Nabi Muhammad ketika Jibril berkata "قراء" ما انا

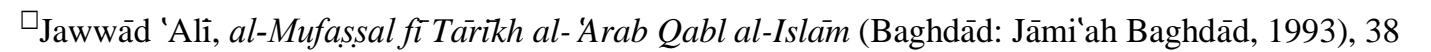

${ }^{2}$ R. H. Tamimi, Muhammad SAW dan Peletakan Dasar Peradaban Islam, Jurnal of Islam and Plurality, Vol. 3, No. 1, (Juni, 2018), 40.

${ }^{3}$ Eva Nugraha “Konsep al-Nabi al-Ummi dan Implikasinya dalam Penulisan Rasm” Refleksi Jurnal Ilmu-Ilmu Ushuludddin, Vol. 12, No. 2, (2011), 102

4'Ali Abd al-Fattāh al-Maghrabi, al-Nubuwah wa al-Anbiya’fí al-Fikr al-Islämī (Kairo: Maktabah Wahbah, 1994), 16-34. Keterangan mengenai sifat wajib nabi dan rasul bisa dilihat dalam setiap kitab yang membahas tentang teologi. 
". Mayoritas intelektual muslim menafsirkan jawaban Nabi Muhammad di atas dengan "Saya tidak bisa membaca". Dengan demikian arti yang terkandung pada huruf Lialah Ma Nafi/pentiadaan. Oleh karena itu, tidak heran bila kesimpulan akhir Nabi Muhammad tidak bisa membaca dan menulis. Selain itu, terdapat satu alasan yang memperkuat bahwa Nabi Muhammad tidak bisa baca tulis yaitu autentitas al-Qur'an akan tercemar bila Nabi Muhammad bisa membaca dan menulis. Jika Nabi Muhammad bisa membaca dan menulis, maka akan muncul anggapan bahwa al-Qur'an merupakan karangan Nabi Muhammad yang dihasilkan dari pengumpulan data yang bersumber dari kitab-kitab suci terdahulu. ${ }^{6}$

Demi menjaga keabsahan al-Qur'an dari kritikan tersebut cendikiawan Muslim mulai menepis dan menampilkan argumen bahwa Nabi Muhammad bukanlah pengarang al-Qur'an. Oleh karena itu, tidak heran bila mayoritas intelektual Muslim berpendapat bahwa Nabi Muhammad saat diutus Allah menjadi Rasul, Nabi Muhammad tidak bisa membaca dan menulis. Keawaman Muhammad dalam baca tulis bukan tanpa alasan, namun hal itu menjadi sebuah dalil kuat akan kemu'jizatan al-Qur'an. Jika Nabi Muhammad bisa baca tulis, para pengingkar kenabian Nabi Muhammad akan berargumen bahwa al-Qur'an adalah karya tangan Nabi Muhammad yang dihasilkan dari belajar, membaca, dan mengetahui sejarah nabi-nabi terdahulu. Oleh karena itu, Allah berfirman (Q.S. al-'Ankabut 48)

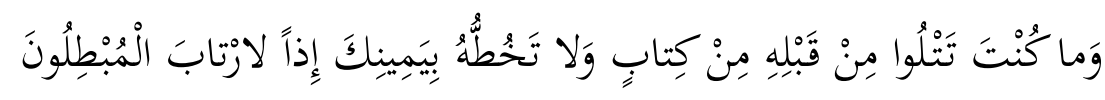

Terjemahnya: "Dan engkau (Muhammad) tidak pernah membaca suatu kitab sebelum (alQur'an) dan engkau tidak (pernah) menulis suatu kitab dengan tangan kananmu; sekiranya (engkau pernah membaca dan menulis), niscaya ragu orang-orang yang mengingkarinya." 7

Dari ayat di atas menjelaskan bahwa Nabi Muhammad adalah seorang utusan yang tidak pernah membaca dan menulis kitab nabi-nabi terdahulu. Jika Nabi Muhammad pernah membaca atau menulis dengan tangan kanannya, maka perbuatan ini mempermudah bagi para pengingkar otentitas al-Qur'an. Jika ayat di atas ditafsir demikian, maka terlihat sukar untuk menghubungkan dengan sifat 'cerdas' yang harus dimiliki oleh seorang nabi. Tidak bisa membaca dan menulis merupakan salah satu

\footnotetext{
${ }^{5}$ Muhammad bin Ismā‘îl al-Bukhārī, al-Saḥị̣ al-Bukhārī (Bairūt: Dar al-Ṭawuq al-Najāh, 1422), $1 / 7$

${ }^{6}$ Aris Fauzan, Al-Nabi al-Ummiy dalam Telaah Historis-Semiotik, Jurnal Kajian Keislaman dan Kemasyarakatan, Vol. 3, No. 1, (Juni, 2018), 43.

${ }^{7}$ Departemen Agama RI, Al-Qur'an dan Terjemahnya, (Bandung: CV Diponegoro, 2008), 402.
}

Tribakti: Jurnal Pemikiran Keislaman

Volume 31, Nomor 1, Januari 2020 
karakter yang dimiliki oleh orang yang tidak cerdas. Jika tidak bisa membaca dan menulis merupakan sifat tercela, maka ayat di atas memerlukan penafsiran lain yang berbeda dari penafsiran intelektual klasik dan modern demi menjaga reputasi Nabi Muhammad. Oleh karena itu, memvonis Nabi Muhammad sebagai seorang Nabi yang tidak bisa membaca dan menulis dengan argumen menepis pengingkar al-Qur'an tidak dapat spontanitas diterima, sebab hal itu dapat merusak reputasi Nabi Muhammad.

Bila ditinjau dari penelitian-penelitian sebelumnya yang membahas tentang hal ini, maka dapat disimpulkan hasil penelitian terbagi menjadi dua argumen besar yaitu: 1) Nabi Muhammad tidak bisa baca tulis. Seperti halnya penelitian yang ditulis oleh R.H. Tamimi. Ia menjelaskan bahwa masyarakat Jahiliyah merupakan masyarakat yang buta huruf, dan Nabi Muhammad berusaha untuk mengentaskan hal itu dengan mengambangkan baca tulis, meski Nabi sendiri tidak bisa baca tulis. ${ }^{8}$ Demikian juga dengan hasil penelitian yang ditulis oleh Mukim. Ia mempertegas bahwa Nabi Muhammad tidak bisa baca tulis dan memberikan kritikan terhadap pandangan Agus Mustafa yang beranggapan Nabi Muhammad bisa baca tulis dengan menggunakan pendekatan ilmu Balaghah. ${ }^{9}$ 2) Nabi Muhammad bisa baca tulis. Hal ini sebagaimana tergambar dari hasil penelitian Aris Fauzan. Ia menjelaskan bahwa salah satu arti al-Nabi al-Ummi tidak dapat baca tulis, namun hal ini tidak cocok disandangkan pada Nabi Muhammad setelah ditinjau dari kajian rasionalitas ilmiah dan teologis, bukan dengan apologetis-teologis. ${ }^{10}$

Melihat adanya dua argumen besar dari hasil penelitian terhadap bisa dan tidaknya Nabi Muhammad baca tulis, terlihat jelas bahwa argumen pertama tidak meninjau keseluruhan arti lafal al-Ummi yang ada dalam al-Qur'an, sehingga memusatkan bahwa arti lafal al-Ummi tidak bisa baca tulis. Sendangkan perbedaan artikel ini dengan argumen kedua, artikel ini lebih terpusat pada tinjauan sosial dan historis tentang tulis menulis yang ada pada masa Jahiliyah yang pada akhirnya menjadi penafsiran dari lafal al-Ummi yang ada dalam al-Qur'an. Dengan demikian, maka akan ditemukan hasil yang lebih sesuai terhadap kandungan lafal al-Ummi yang disandarkan pada Nabi Muhammad.

Bila dilihat dari sudut pandang historis dan sosiologis, tradisi tulis menulis merupakan bagian yang tidak bisa terpisahkan dari orang-orang Jahiliyah, sebab pada era

\footnotetext{
${ }^{8}$ Tamimi, Muhammad SAW dan Peletakan Dasar Peradaban Islam, 25.

${ }^{9}$ Mukmin, Konsep Keummian Nabi Muhammad dalam al-Qur'an (Tela'ah Kritis Terhadap Pemikiran Agus Mustofa dalam Perspektif Ilmu Balaghah), Proseding Konferensi Nasional Bahasa Arab III, (Malang: Oktober, 2017), 552.

${ }^{10}$ Aris Fauzan, Al-Nabi al-Ummiy dalam, 62. 
Jahiliyah tulis menulis menjadi bagian yang sangat penting bagi kehidupan saat itu. Sebagai pertimbangan tradisi tulis menulis pada masa Jahiliyah ialah masyarakat Jazirah Arab khususnya suku Quraisy terkenal sebagai pedagang. Bagi pedagang tulis menulis dan membaca merupakan kebutuhan pokok untuk mencatat transaksi yang dilakukan. Dari sini bisa dikatakan membaca dan menulis merupakan sebuah kewajaran yang sudah berjalan dengan baik.

Audisi keindahan sastra menjadi kebanggaan pada masa Jahiliyah dan tingkat sastra tertinggi akan mendapatkan penghargaan berupa karya sastranya akan dipampang di pintu Ka'bah. Selain itu, sepuluh paman Nabi Muhammad tergolong orang yang terkenal bisa membaca dan menulis sebagaimana yang tercatat dalam sejarah. Dari penjelasan tersebut sudah bisa menjadi bahan dasar atas penepisan argumen ulama klasik dan modern yang beranggapan Nabi Muhammad tidak bisa menulis dan orang yang menulis menjadi tanda orang yang tidak kuat hafalannya. Oleh karena itu, butuh adanya penelitian ulang perihal arti lafal al-Ummi dalam al-Qur'an dengan menggunakan pendekatan sosiologi dan historis. Dengan demikian, akan ditemukan maksud dari lafal al-Ummi yang ada dalam al-Qur'an. Hemat penulis, pembahasan ini butuh diangkat, agar supaya dapat menjadi media terbukanya wawasan dan fakta sejarah yang lebih akurat terhadap literasi pada masa Jahiliyah dan literasi Nabi Muhammd

\section{Metode Penelitian}

Jenis data penelitian yang digunakan dalam penelitian ini ialah penelitian kualitatif. Adapun sumber penelitan ini menggunakan riset kepustakaan murni, dalam arti seluruh sumber datanya berasal dari data-data tertulis yang memiliki keterkaitan dengan topik yang dibahas. Dalam buku Mustika aed Metode penelitian Kepustakaan dijelaskan terdapat empat langkah penelitian kepustakaan yaitu: ${ }^{11}$

1. Menyiapkan alat perlengkapan, alat perlengkapan dalam penelitian kepustakaan hanya pensil atau pulpen dan kertas catatan.

2. Menyusun biblografi kerja, biblografi kerja adalah caatan mengenai bahan sumber utama yang akan dipergunakan untuk kepentingan penelitain. Sebagian besar sumber binliografi berasal dari koleksi perpustakaan yang dipajang atau yang tidak dipajang.

${ }^{11}$ Khatibah, Penelitian Kepustakaan, Jurnal Iqra' Volume 05 No 01, 2011, 38-39. 
3. Mengatur waktu, dalam hal ini tergantung personal yang memanfaatkan yang ada, bisa saja merencanakan berapa jam satu hari, satu bulan, terserah bagi personal yang bersangkutan memanfaatkan waktunya.

4. Membaca dan membuat catatan penelitian, artinya apa yang dibutuhkan dalam penelitian tersebut dapat dicatat, supaya tidak bingung dalam lautan buku yang begitu banyak.

Melihat dari judul artikel ini adalah al-Ummi Dalam al-Qur'an: Studi Tafsir Tematik Terhadap Literasi Nabi Muhammad, maka sumber data yang berkaitan dengan penelitian ini adalah kitab-kitab yang membahas tentang bahasa Arab khususnya yang membahas mengenai arti kosakata al-Ummi. Kemudian untuk menyempurnakan penelitian dan menjadi pembeda dari penelitian terdahulu, membutuhkan kitab-kitab yang menjelaskan tentang kehidupan sosial dan budaya orang-orang Arab pra terutusnya Nabi Muhammad.

Mengingat penelitian ini bersangkutan pada al-Qur'an yang dikhususkan terhadap kalimat al-Ummi yang ada dalam al-Qur'an dan kehidupan sosial budaya orang Arab, maka penedekatan utama yang akan digunakan ialah pendekatan tafsir Tematik (Maudhu'i). Menurut 'Id Khadhr Muhammad metode tafsir tematik ini ialah metode penafsiran yang membahas mengenai tema yang tertentu dari kitab Allah (al-Qur'an). ${ }^{12}$ Menggunakan tafsir secara tematik dalam membahas kalimat al-Ummi yang ada dalam al-Qur'an merupakan metode yang paling tepat, sebab penulis terlebih dahulu menghimpun semua lafad al-Ummi yang ada dalam al-Qur'an, kemudian menfsirkan satu-persatu dari lafad tersebut.

Muhammad 'Ali al-Radaĩ menjelaskan mengenai definisi tafsir Maudu' $\bar{\imath}$, mengumpulkan setiap ayat yang berhubungan dengan tema yang dibahas, kemudia menafsirkannya dengan menggunakan metode penafsiran al-Qur'an dengan al-Qur'an, mencari titik temu antara satu ayat dengan ayat lainnya, kemudia memberikan kesimpulan akhir terhadap ayat yang telah ditafsirkannya. ${ }^{13}$ Beda halnya dengan Sulaiman al-Rumi, ia mendefinisikan tafsir Maudu'st, konsep yang mana penafsirnya tidak menafsirkan ayat al-Qur'an sebagaimana tartib ayat yang ada dalam al-Qur'an, akan tetapi ia mengumpulkan ayat-ayat dengan satu tema pembahasan lantas menafsirkannya. ${ }^{14}$ Pada

${ }^{12}$ 'Id Khadhr Muhammad Khadhr, al-Idhah wa al-Bayan fi 'Ulum al-Qur'an, (Kairo: Maktabah Wahbah, 2002), 354.

${ }^{13 ،}$ Ali al-Radhai, Manahij al-Tafsir, 419.

14 'Abdurrahman al-Rumi, Buhuts fi Ushul al-Tafsir, 62. 


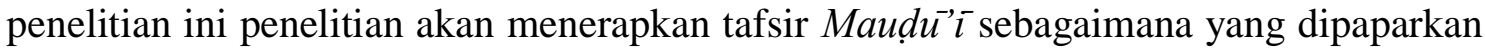
oleh Sulaiman al-Rumi di atas.

Langkah selanjutnya ialah menganalisis kebenaran dari sudut pandang sosial menjadi pembantu dalam penyelesaian penelitian ini, sebab dengan mengetahui kodisi sosial masyarat Arab Jahiliyah menjadi salah satu sumber kuat akan ada atau tidaknya tulis menulis pada saat itu. Menurut Abu Ahmadi titik tekan pendekatan sosial (The Societal Approach) ini adalah masyarakat dengan berbagai lembaga, kelompok, organisasi dan aktivitasnya. Secara kongkrit pendekatan sosial ini membahas aspek-aspek atau komponen dari kebudayaan manusia, seperti keluarga, tradisi, adat-istiadat, dan sebagainya. ${ }^{15}$

Oleh karena yang dibahas dalam penelitian ini bersangkutan dengan kehidupan sosial pada masa Jahiliyah, maka pendekatan yang digunakan ialah pendekatan sejarah Arab Jahiliyah. Raja' Wahid mendefinisikan pendekatan historis ini dengan kumpulan pendekatan yang digunakan oleh seseorang yang meneliti sejarah untuk mendapatkan kebenaran sejarah, membangun ulang sejarah yang sudah lewat meninjau kejadian dari sudut-sudut yang ada sebagaimana yang ada pada ruang dan waktu saat itu. Raja' juga menjelaskan bahwa pendekatan historis ini masih memiliki kemungkinan untuk selalu berkembang dan menerima untuk selalu disempurnakan mengikuti perkembangan pengetahuan manusia dan kelengkapan media. ${ }^{16}$ Dengan metode dan pendekatan ini, maka menghasilkan sebuah pemaknaan yang akurat terhadap lafal al-Ummi yang ada dalam al-Qur'an.

\section{Pembahasan}

\section{Perkembangan Tulis Menulis di Jazirah Arab}

Sebelum masuknya ajaran agama Islam di Makkah, tradisi tulis menulis terlebih dahulu telah berkembang, meskipun belum menjadi sebuah budaya. Asumsi ini diperkuat dengan hasil penelitian yang ditulis oleh Dahrun Sarif, ia menjelaskan, "belum membudayanya tulis menulis tidak menafikan tulis menulis sudah muncul pada saat itu. ${ }^{17}$ Dengan demikian, maka tulis menulis merupakan suatu aktifitas yang telah lumrah bagi masyarakat Makkah.

\footnotetext{
${ }^{15}$ Abu Ahmadi, Sosiologi Pendidikan, (Jakarta: PT Raja Grafindo Persada, 2007), 37.

${ }^{16}$ Raja' Wahid Duwaidari, al-Bahts al-'Ilmi Asasiyah al-Nadzariyah wa Mumarasah al-'Ilmiyah, (Bairut: Dar al-Fikr al-Mu'asir, 2000), 151.

${ }^{17}$ Dahrun Sarif, Pengaruh Alquran Terhadap Perkembangan Kaligrafi Arab, Jurnal Etnohistori, Vol. III, No. 2, (2016), 167.
} 
Butuhnya terhadap tulis menulis ini bisa dilihat dari lingkungan dan kondisi sosial yang ada di daerah Makkah yaitu: menjadi pusat perdagangan dunia pada saat itu. ${ }^{18}$ Sejarah mencatat terdapat 17 orang yang mahir dalam menulis di kota Makkah, di antaranya dari golongan laki-laki Abd al-Mụtallib bin Hāshim, 'Umar bin Khạtab, 'Ali bin Abi Ṭalib, 'Uthmān bin 'Affān, Yazid bin Abi Safyan. Dari golongan perempuan di antaranya: 'Aishah bint Sa'd yang belajar tulis menulis dari ayahnya sendiri. Tulis menulis juga berkembang di Madinah di antaranya adalah: Sa'd bin 'Ubbādah, alMandhūr bin 'Amr, Zaid bin Thābit, Nafi' bin Malilk, Asid bin Hudair, Mu'an bin Adi, Bashir bin Sa‘d, Abdullah bin Ubai, dan lainnya. ${ }^{19}$

Masyarakat Makkah dan Madinah menjadikan Tulis menulis sebagai media penulisan perjanjian, sumpah, perdagangan, dan surat-menyurat. ${ }^{20}$ Sebagai bukti adanya tulisan pada masa sebelum kedatangan ajaran Islam ialah tulisan kakek Nabi Muhammad yaitu Abd al-Muthallib bin Hasyim yang ditulis pada kulit hewan. Tulisan itu masih terjaga hingga masa Khalifah Abbasi al-Ma'mun (198-218 H). ${ }^{21}$ Isi dari tulisan Abd alMuthallib adalah:

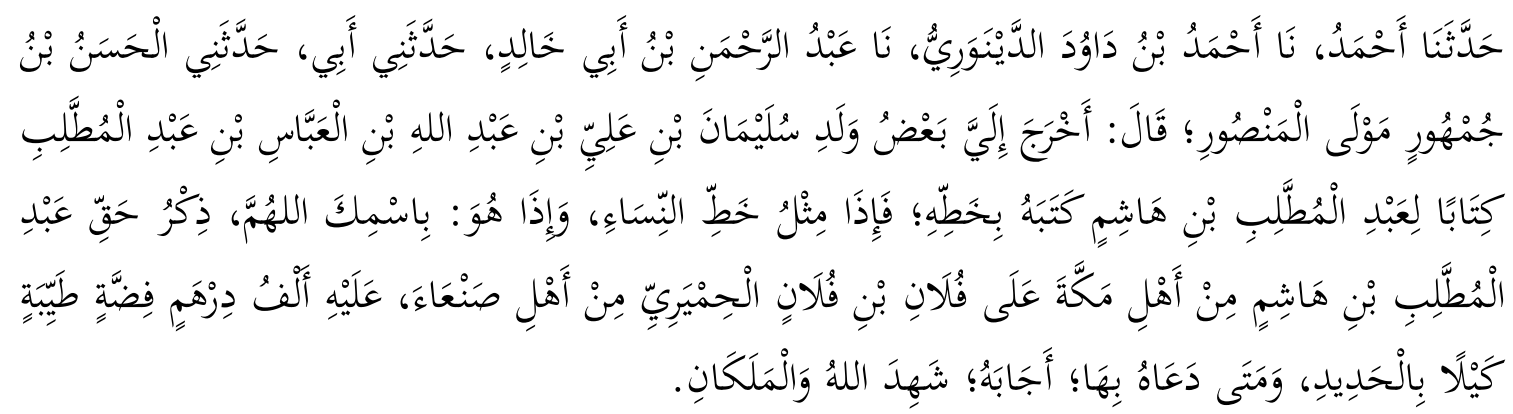

Artinya: “Abdul Muthalib bin Hisyam dari penduduk Makkah bersumpah pada fulan bin fulan al-Humair dari penduduk Shan'a', akan memberikan seribu dirham perak dengan ukuran timbangan dari besi. Dan ketika ia memintanya Abdul Muthalib memenuhi sumpahnya."

Dalam kitab al-Sirah al-Nabawiyah karya Ibn Hishām dijelaskan bahwa anak dari Abdul Mụtallib pandai dalam bidang tulis menulis. ${ }^{22}$ Pendapat Ibn Hishām ini diperkuat oleh Ibn Sa'd dalam kitabnya al-Tabaqāt. Di dalam karyanya ia mencantumkan sebuah riwayat yang menjelaskan nazar Abdul Mụtallib untuk berkurban di Ka’bah jika ia

\footnotetext{
${ }^{18}$ Ahmad Hanif Fahruddin, Learning Society Arab Pra Islam (Analisis Historis dan Demografis), Jurnal Kuttab, Vol. 1, No. 1, (Maret, 2017), 42.

${ }^{19}$ Yahya Wahib al-Jubairi al-Khath wa al-Kitabah fi al-Hadharah al- 'Arabiyah (Bairut: Dar alGharb al-Islami, 1994), 40.

${ }^{20}$ Ahmad bin Yahya bin Jabir, Futuh al-Buldan (Kairo: Lajnah al-Bayan al-'Arab, 1957), 3/580.

${ }^{21}$ Muhammad bin Ishaq bin Ya'qub, al-Fihrit li Ibn al-Nadim (Mesir: al-Maktabah al-Tijariyah, 1348), 5.

${ }^{22}$ Abd al-Malik bin Hisyam, al-Sirah al-Nabawiyah (Mesir: al-Halaby, 1936), 1/160.
} 
memiliki 10 anak. Setelah ia memiliki 10 anak nazar itu ia tepati dan ia berkata pada anakanaknya, "Ambillah setangkai daun dan tulislah namamu pada daun lantas berikan padaku." 23

Israil Walifansun menjelaskan dalam karyanya yang berjudul Tärikh al-Lughāt alSamiyah, "tulisan yang pernah ada pada masa sebelum tersebarnya Islam tidak ada satupun yang sampai pada tangan kita. Hal itu disebabkan minimnya orang-orang yang menyimpan jejak di Jazirah Arab." ${ }^{24}$ Penjelasan ini bisa diambil kesimpulan bahwa pada masa Jahiliyah tradisi tulis menulis sudah berjalan dengan mulus dan banyak kaum Arab Jahiliyah yang mahir dalam bidang tulis menulis. Dengan demikian, maka argumentasi atas julukan Jahiliyah sebagai kaum yang buta huruf merupakan sebuah kesalahan, sebab tulis menulis pada masa Jahiliyah sudah tersebar. Lebih dari itu, Nabi Muhammad terlahir dari keluarga yang bisa membaca dan menulis sebagaimana yang tercantum dalam riwayat dari Ibn $\mathrm{Sa}^{\circ} \mathrm{d}$ dalam karyanya al-Tabaqāt. Realita historis ini menepis definisi Jahiliyah sebagai kaum yang buta huruf.

Jika mayoritas intelektual Muslim berpendapat bahwa tulis menulis merupakan sesuatu yang tercela di masa Jahiliyah dengan argumen hafalan yang tidak kuat, maka ungkapan ini sangat tidak masuk akal dan pendapat ini hanya ideologi yang tidak didasari sejarah yang kuat, sebab buku-buku sejarah telah mencatat tulis menulis menjadi kebutuhan pokok bagi pedagang dan keunggulan dari Bani Hāshim.

Selain itu, terdapat bukti kuat bahwa Nabi Muhammad bisa membaca dan menulis berdasarkan penulisan al-Qur'an yaitu (H.R. Zaid bin Thabit: 4888/142/5)

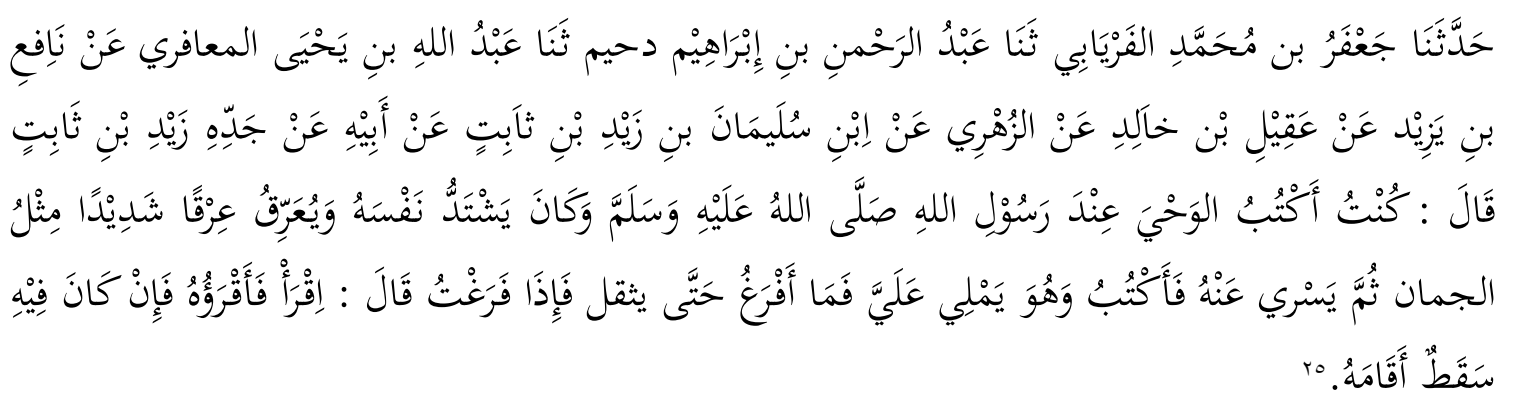

Riwayat di atas mengindikasikan Nabi Muhammad bisa membaca dan menulis, dengan dasar setelah Zaid bin Thabit merampungkan tulisannya, Nabi Muhammad

\footnotetext{
${ }^{23}$ Muhammad bin Muni’ al-Zuhri, al-Thabaqat al-Kubra (Mesir: al-Maktabah al-Tijariyah, 1345), $4 / 108$

${ }^{24}$ Israil Walifansun, Tarikh al-Lughat al-Samiyah, (Mesir: Mathba'ah al-I’timad, 1348), 194.

${ }^{25}$ Sulaiman bin Ahmad bin Ayyub al-Thabrani, al-Mu'jam al-Kabir, (Bairut: Maktabah al-'Ulum wa al-Hukm, 1404), 5/142.
} 
memerintah Zaid membaca ulang tulisan itu. Jika terdapat kesalahan atau kekurangan dalam tulisannya, Nabi Muhammad akan meluruskan tulisan tersebut.

Berdasarkan hadis di atas mayoritas intelektual Muslim sepakat bahwa tulisan alQur'an bersifat Tauqifi (bersumber dari Nabi dan Allah) bukan ijtihad Zaid bin Thabit atau sekretarisnya dalam penulisan al-Qur'an yang berjumlah 43 orang. ${ }^{26}$ Jika Nabi Muhammad tidak bisa baca tulis, maka pendapat para ulama yang mengatakan tulisan alQur'an bersifat Tauqifi bisa melemah, sebab tidak dapat dikatakan Tauqifi sedangkan Nabi Muhammad sendiri tidak bisa membaca dan menulis dan ketidak tahuan Nabi Muhammad dalam baca tulis, tidak mungkin Nabi Muhammad dapat membenarkan tulisan dari para penulis al-Qur'an bila terjadi suatu kesalahan.

\section{Pengulangan Lafad al-Ummi dalam al-Qur'an}

Dalam al-Qur'an lafad al-Ummi (لامي)terdapat tujuh kali pengulangan, namun terdapat satu pembahasan dari pengulangan lafad al-Ummi yang tidak masuk dalam pembahasan penelitian ini, sebab lafad al-Ummi yang terdapat pada surat al-Maidah: 116 sangat jelas memiliki arti ibu. Di bawah ini adalah table pengulangan lafad al-Ummi mengikuti tartib Nuzul yang digunakan oleh Muhammad Izzat Darwazah dalam kitab tafsirnya al-Tafsir al-Hadith ${ }^{27}$

\begin{tabular}{|c|c|c|c|c|c|}
\hline No & Surah & $\begin{array}{c}\text { T. } \\
\text { Nuzul }\end{array}$ & $\begin{array}{c}\text { T. } \\
\text { Mushaf }\end{array}$ & Makki & Madani \\
\hline 1 & 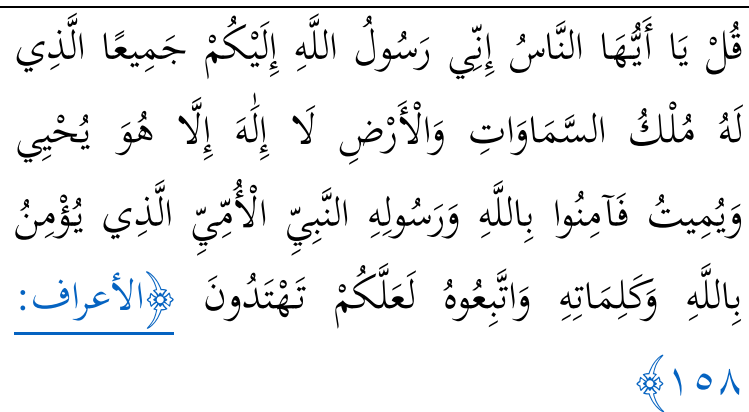 & 39 & 7 & $\checkmark$ & \\
\hline 2 & 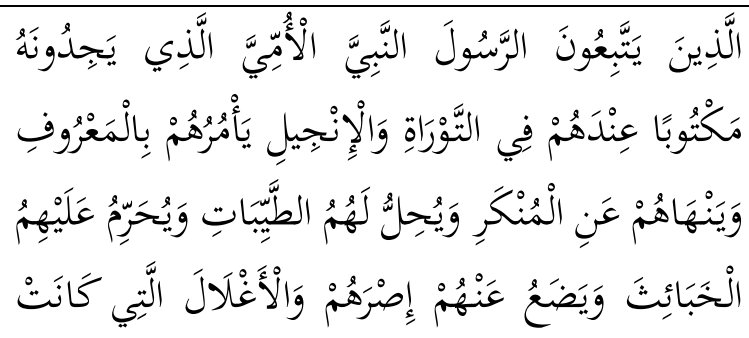 & 39 & 7 & $\checkmark$ & \\
\hline
\end{tabular}

${ }^{26}$ Jumlah skertaris Nabi Muhammad berjumlah 43 orang bisa dilihat keterangannya dari kitab karya Ghanim Qaddawari al-Hamd, Rasm al-Mushhaf Dirasah Lughawiyah Tarikhiyah (Baghdad: Lajnah alWathaniyah, 1402), 94.

${ }^{27}$ Muhammad Izzah Darwazah, al-Tafsir al-Hadits (Kairo: Dar al-Ihya’ al-Kutub al-'Arabiyah, 1383), 15-16. 


\begin{tabular}{|c|c|c|c|c|}
\hline & 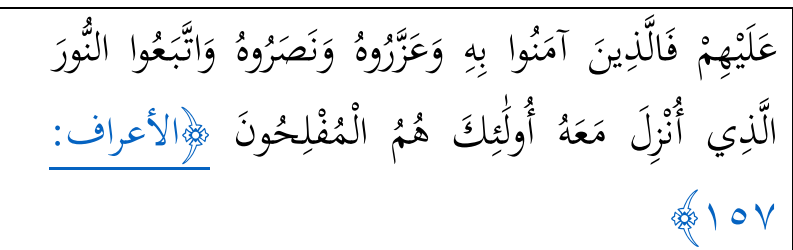 & & & \\
\hline 3 & 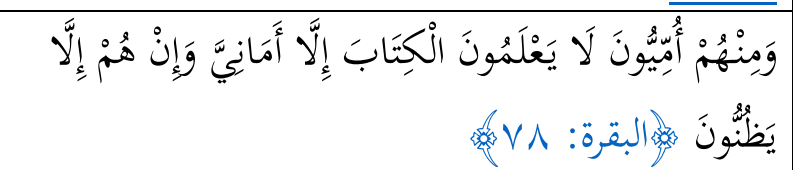 & 87 & 2 & $\checkmark$ \\
\hline 4 & 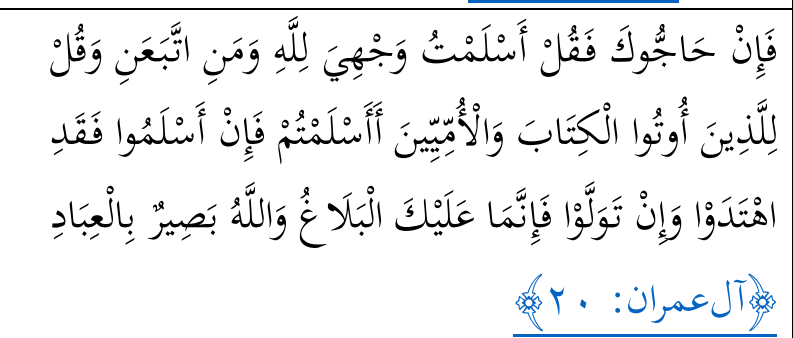 & 89 & 3 & $\checkmark$ \\
\hline 5 & 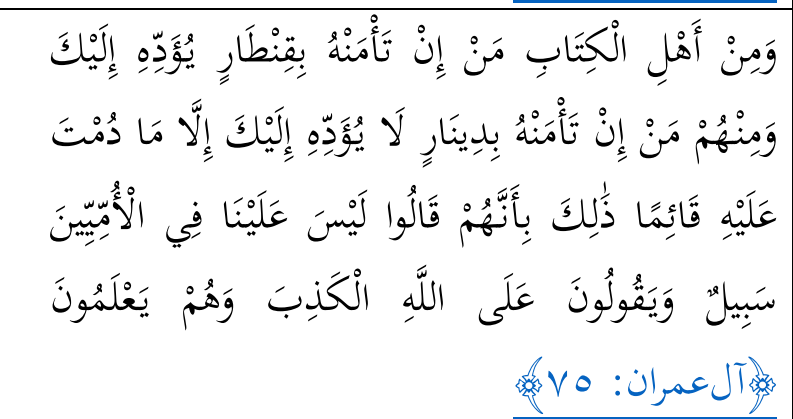 & 89 & 3 & $\checkmark$ \\
\hline 6 & 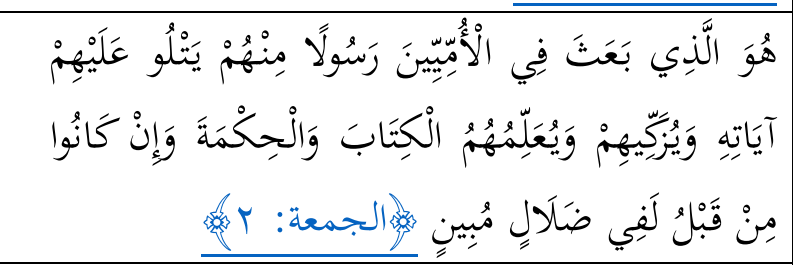 & 110 & 62 & $\checkmark$ \\
\hline 7 & 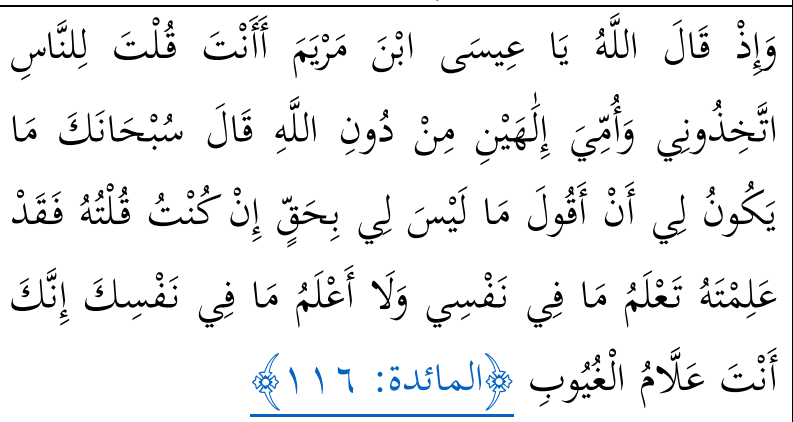 & 112 & 5 & $\checkmark$ \\
\hline
\end{tabular}

\section{Arti Lafad al-Ummi Menurut Para Ahli Bahasa Arab}

Sebagaimana yang telah masyhur dikalangan umat Islam, lafad al-Ummi memiliki arti tidak bisa membaca dan menulis. Oleh karena itu, secara spontan mengartikan lafad al-Ummi yang disandarkan pada Nabi Muhammad dengan menggunakan arti tidak bisa membaca dan menulis. Padahal bila dilihat dari kamus bahasa Arab, lafal al-Ummi 
memiliki beragam arti yaitu: 1) Tidak fasih dalam bicara atau sedikit bicara, ${ }^{28}$ 2) Orangorang Arab, 3) Orang Yahudi, 4) Tidak bisa membaca dan menulis, ${ }^{29}$ 5) Minim pengetahuan, 6) Orang Arab yang tidak memiliki kitab suci. ${ }^{30}$

Mengenai ragam arti yang dikandung dalam lafal al-Ummi, terdapat salah satu penelitian yang menegaskan bahwa lafal al-Ummi memiliki enam arti yaitu: 1) orangorang yang belum pernah menerima dan bersinggungan dengan al-Kitab. 2) orang-orang yang belum pernah didatangi oleh seorang Nabi atau Rasul. 3) orang-orang yang buta huruf, tidak bisa membaca dan menulis. 4) orang-orang yang terbelakang dan jauh dari kemajuan peradaban dan kemajuan. 5) orang-orang yang dihinakan dan pantas untuk dibodoh-bodohi atau ditipu. 6) orang-orang yang terbiasa dengan hal-hal mistis dan sihir. $^{31}$

Dari semua arti yang telah dipaparkan di atas, semuanya memiliki kemungkinan untuk menjadi arti dan maksud dari lafal al-Ummi yang ada dalam al-Qur'an. Namun, tidak semua arti yang terkandung dalam lafal al-Ummi bisa menyandang maksud alUmmi yang disandarkan pada Nabi Muhammad.

\section{Interpertasi Lafad al-Ummi dalam al-Qur'an}

Setelah mengetahui kondisi sosial, perkembangan tulis menulis mulai dari masa Jahiliyah hingga tersebarnya ajaran Islam di Jazirah Arab, dan mengetahui ragam arti yang terkandung dalam lafal al-Ummi, beralihlah pembahasan penafsirannya ayat-ayat yang mengandung lafal al-Ummi. Dalam menafsirkan 7 ayat yang menggunakan lafal alUmmi ini mengikuti tartib turunnya surat (di mulai dari ayat Makkiyah, kemudian diteruskan dengan ayat Madaniyah), sebab bila ditinjau dari tertib turunnya ayat akan ditemukan sambungan antar satu ayat dengan ayat yang lain. Di bawah ini merupakan penafsiran dari ayat-ayat yang mengandung lafal al-Ummi.

Dilihat dari tartib turunnya ayat, maka surat al-A'raf adalah surat pertama yang mencantumkan lafal al-Ummi. Terjadi dua kali pengulangan lafal al-Ummi dalam surat al-A'raf yang terletak pada ayat ke 157 dan 158. Lafal al-Ummi dalam surat ayat ini memiliki arti orang Arab, bukan orang yang tidak bisa membaca dan menulis. Hal ini meninjau terhadap sebuah riwayat dari Qatādah bahwa pada dasarnya orang Yahudi dan

\footnotetext{
${ }^{\square}$ Muhammad bin Mukram bin Mandzur al-Afriqi al-Mashri, Lisān al- 'Arab (Kairo: Dar al-Ma'arif, 1990), 138.

${ }^{29}$ Husain bin Muhammad al-Damaghani, Qamus al-Qur'an aw Ishlah al-Wujuh wa al-Nadzair fi alQur'an al-Karim (Bairut: Dar al-'Ilm li al-Malayin, 1980), 45.

${ }^{30}$ Raghib al-Ashfahani, al-Mufradat fi Gharib al-Qur'an (Bairut: Dar al-Ma'rifah, t.t), 23.

${ }^{31}$ Mukmin, Konsep Keummian Nabi Muhammad dalam al-Qur'an, 552. 
Nashrani sudah mendengar kabar kedatangan Nabi akhir zaman, oleh karena itu mereka sangat mengharapkan kehadirannya. Bahkan setiap kali mereka tertimpa musibah, mereka berdoa dengan menggunakan kata perantaraan Nabi yang akan datang pada akhir zaman, akan tetapi setelah kehadirannya Nabi akhir zaman mereka kufuri sendiri hanya dengan alasan Nabi yang diutus bukan dari golongannya. Keterangan ini bisa dilihat dari riwayat Qatadah:

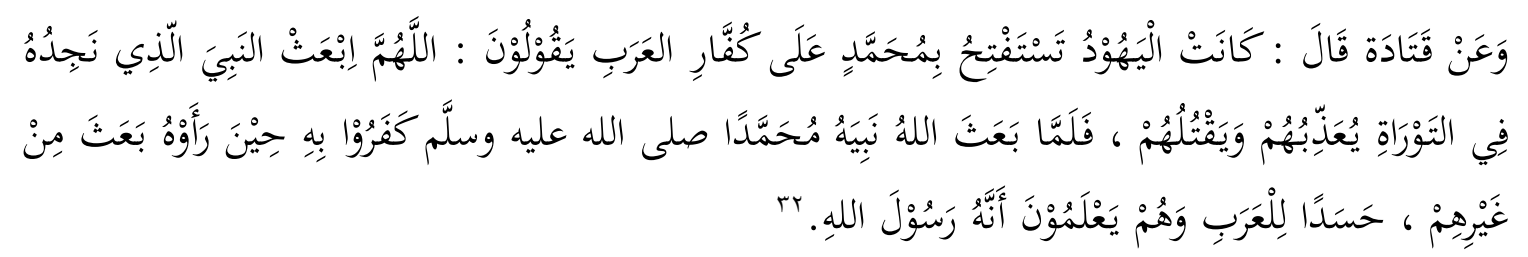

Artinya: "Dari Qatadah, ia berkata, "Ketika orang-orang Yahudi mendapatkan kabar akan kehadiran Muhammad yang bisa mengalahkan orang kafir Arab, mereka berdoa, Ya Tuhan utuslah seorang Nabi sebagaimana yang telah kami temukan dari kitab Taurah yang akan menyiksa dan membunuh orang Arab.” Ketika Allah telah mengutus nabi-Nya (Nabi Muhammad), mereka mengkufurinya, sebab nabi yang diutus bukan dari kalangan mereka, meski mereka mengetahui bahwa Muhammad adalah Nabi. hal itu mereka lakukan, disebabkan mereka benci terhadap orang Arab."

Jika pada ayat 157 sudah dijelaskan kedatangan Nabi akhir zaman dalam kitab-kitab suci terdahulu, pada ayat 158 menjelaskan perintah Allah kepada Nabi Muhammad untuk menyatakan secara jelas kepada orang Yahudi, Nashrani, dan semua manusia bahwa dirinya utusan dan Rasul Allah. Dan diperintahkan Allah untuk menyerukan iman kepada Allah serta Rasul-Nya yang berasal dari orang Arab.

Surat Madaniyah yang menjelaskan lafadh al-Ummi terdiri dari 5 ayat. Lafal alUmmi yang tercantum dalam surat Madaniyah memiliki tiga arti yaitu orang-orang yang tidak pernah mendengarkan bacaan kitab suci (surat al-Baqarah: 78), orang Arab (surat Ali ‘Imran: 20, 75 dan al-Jum’ah: 2) dan dengan arti ibu (al-Maidah: 116).

Bila diartikan kembali dari surat al-Baqarah ayat 78 sebagaimana berikut: di antara Ahli Kitab ada yang tidak pernah mendengarkan bacaan kitab suci yang diturunkan Allah pada nabi-Nya atau dengan menggunakan arti di antara Ahli Kitab ada yang sangat minim pengetahuan tentang kitab suci yang diturunkan untuknya. Mereka hanya menduga-duga, sedangkan dugaannya salah. Sedangkan dalam surat Ali 'Imrān: 20 memiliki sebuah pemahaman: tugas Nabi Muhammad adalah menyebarkan dakwah Islam kepada semua

${ }^{32}$ Ahmad bin 'Ali al-Muqrizi, Imta' al-Asma' bi ma li al-Nabi min al-Ahwal wa al-Amwal wa alHafadah wa al-Mata' (Bairut: Dar al-Kutub al-'Ilmiyah, 1420), 3/359.

Tribakti: Jurnal Pemikiran Keislaman

Volume 31, Nomor 1, Januari 2020 
umat manusia. Pada surat Ali 'Imran ayat 20, Nabi Muhammad mendapatkan perintah dari Allah untuk memberikan tawaran kepada Ahli Kitab dan orang-orang Arab yang ada di sekitarnya agar beriman dan masuk agama Islam yang dibawanya. Lafad al-Ummi yang ada pada ayat di atas tidak bisa diartikan orang yang tidak bisa membaca atau menulis, sebab orang-orang Arab sudah banyak yang bisa membaca dan menulis. Terlebih ayat ini turun di Madinah, orang-orang Madinah banyak yang mahir dalam tulis menulis.

Pada surat Ali 'Imrān: 75 menjelaskan perilaku orang-orang Ahli Kitab yang sewenang-wenang. Mereka beranggapan bahwa memakan harta orang-orang Arab halal hukumnya. Arti lafal al-Ummi yang terdapat dalam ayat ini tidak memiliki arti orang yang tidak bisa baca tulis, melainkan memiliki arti orang-orang Arab. Dalam kitab Tafsir al-Qur'an al-'Adzim karya Ibn Katsir juga menjelaskan bahwa lafad al-Ummi berarti orang Arab. ${ }^{33}$ Demikian juga dengan maksud surat al-Jum'ah: 2 adalah Allah mengutus seorang utusan pada orang-orang Arab yang gersang Akidah dan menyimpang dari kebenaran, agar utusannya bisa membacakan ayat-ayat Allah. Dengan jelas ayat di atas tidak menunjukkan lafad al-Ummi berarti orang yang tidak bisa baca tulis, akan tetapi alUmmi memiliki arti orang Arab.

Selain ayat-ayat yang menggunakan lafad al-Ummi di atas, terdapat satu ayat yang selalu dijadikan dasar oleh orang-orang yang beranggapan bahwa Nabi Muhammad tidak bisa membaca dan menulis. Ayat itu tercantum dalam surat al-‘Ankabut: 48.

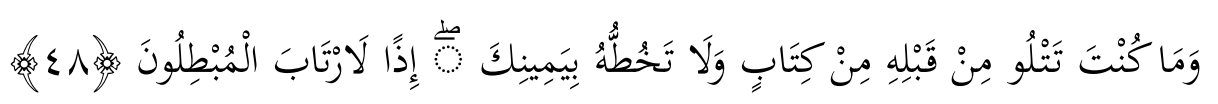

Terjemahnya: "Dan kamu tidak pernah membaca sebelumnya (Al Quran) suatu Kitabpun dan kamu tidak (pernah) menulis suatu kitab dengan tangan kananmu; andaikata (kamu pernah membaca dan menulis), benar-benar ragulah orang yang mengingkari(mu)." 34

Ayat ini sama sekali tidak mengindikasikan bahwa Nabi Muhammad tidak bisa membaca dan menulis, melainkan sebuah pembelaan untuk Nabi Muhammad yang telah dituduh pernah membaca kitab-kitab suci terdahulu serta Nabi Muhammad tidak pernah mencatat isi kitab-kitab suci terdahulu. Kata "Tidak pernah membaca" dan "Tidak pernah menulis" bukan perarti tidak bisa membaca dan tidak bisa menulis. Sebagai contoh, jika ada yang bertanya “Apakah Anda pernah membaca kitab al-Qur'an Kain Hayy?), kemudian dijawab, "Saya tidak pernah membacanya". Apakah jawaban ini menunjukkan t,t) $2 / 61$.

${ }^{33}$ Isma'il bin 'Umar bin Katsir al-Qursyi, Tafsir al-Qur'an al- 'Adzim, (Mesir: Dar al-Kutub al-Misr, ${ }^{34}$ Ibid. 402. 
bahwa penjawab tidak bisa membaca kitab? Demikian pula dengan kata tidak pernah mencatat kitab-kitab sebelumnya.

\section{Wahyu Pertama dan Kemampuan Baca Tulis}

Terdapat riwayat yang menjadikan dasar bahwa Nabi Muhammad tidak bisa membaca dalam menulis adalah hadis riwayat 'Aishah saat pertama kali wahyu diturunkan (H.R. Bukhari: 3/7/1)

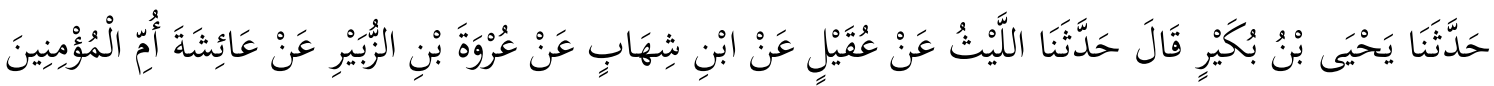

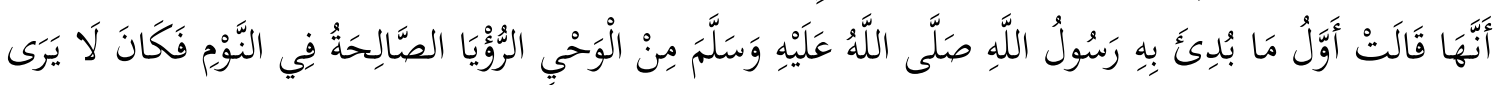

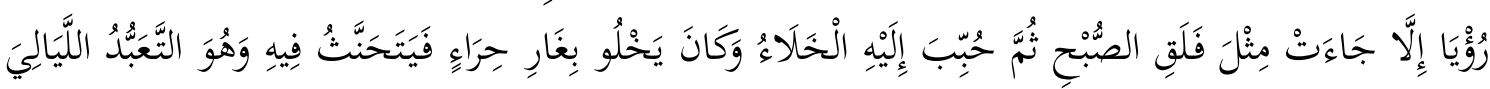

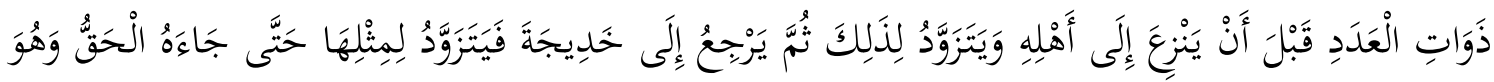

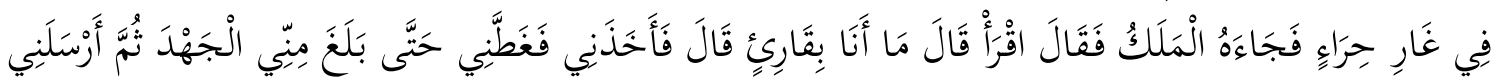

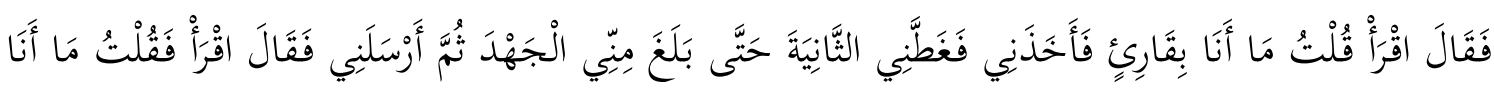

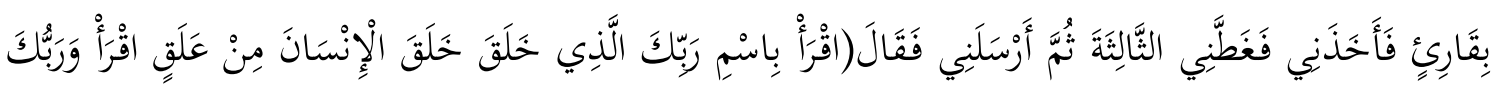

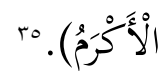

Dalam riwayat lain dari Ibn Ishaq terdapat redaksi lain sebagaimana berikut:

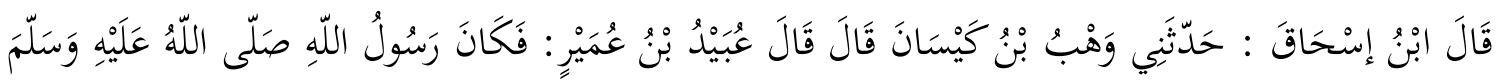

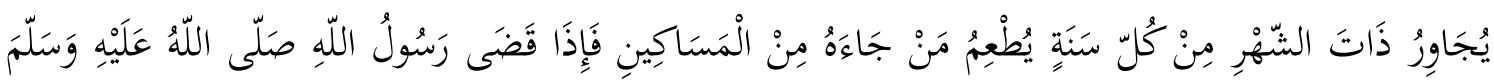

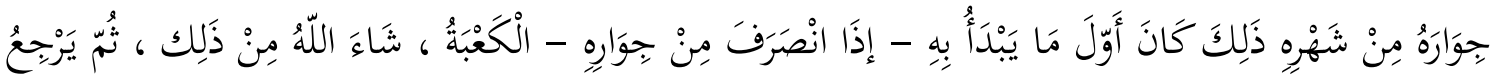

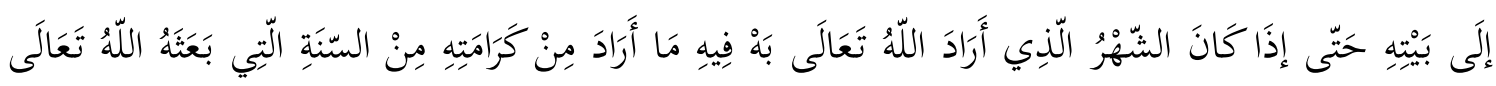

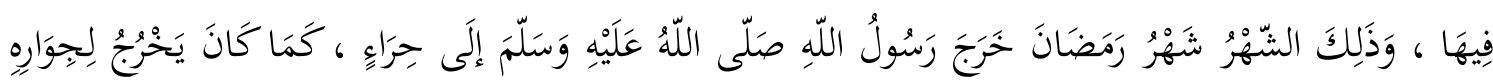

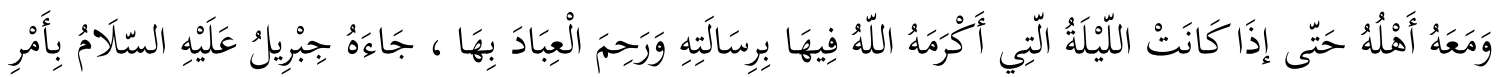

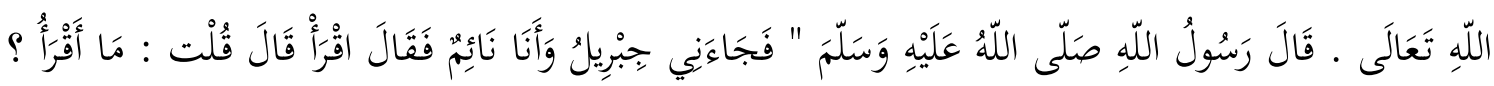

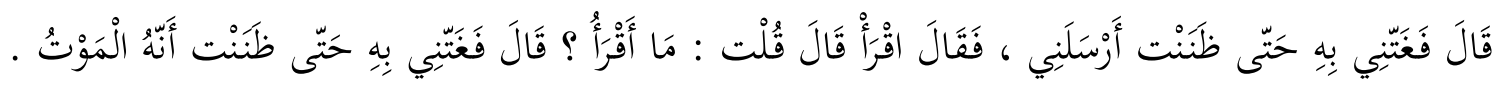

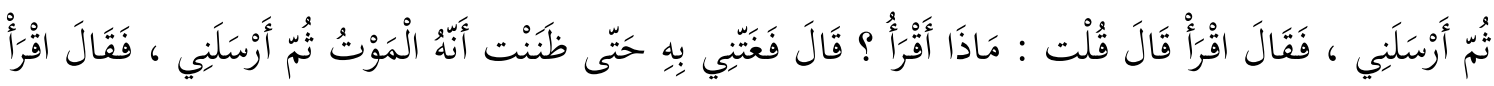

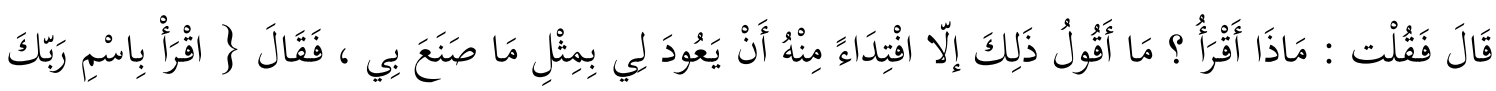

${ }^{35}$ Muhammad bin Isma'il bin Ibrahim bin Mughirah al-Bukhari, Jami' al-Musnad al-Sshahih alMukhtashar min 'Umur Rasulillah (Dar: Thauq al-Najah, 1422), 1/7. 


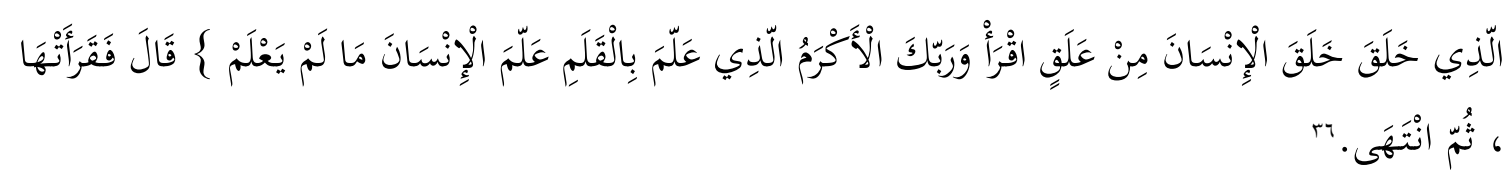

Bila dilihat dari riwayat yang datang dari Ibnu Ishāq (hadis yang kedua), maka dapat divonis bahwa huruf ' $m a$ ' merupakan Istifhamiyah (bermaksud untuk bertanya) yaitu

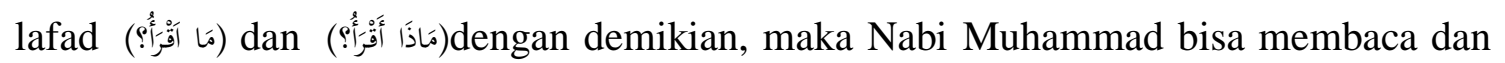
menulis, sebab Nabi Muhammad bertanya pada Jibril 'Apa yang akan saya baca?' Adapun riwayat pertama yang datangnya dari al-Bukhari menggunakan kalimat (مَا آَنَ بِقَارِئ(). Bila difahami dari susunan kalimat, maka Huruf ' $m a$ ' di sini bermakna nafi atau dengan artian tidak bisa membaca.

Setelah memahami dua hadis yang berbeda redaksi, maka yang dibutuhkan dalam memahaminya harus menggunakan pendekatan bahasa. Jika huruf ' $m a$ ' yang ada pada

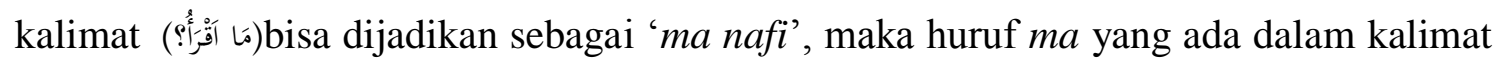
(مَا آنَا بِقَارِئ)bisa diartikan sebagai ma Istifhamiyah dan huruf $b a$ ’ berposisi sebagai huruf tambahan (Zaidah), namun riwayat yang datangnya dari Ibnu Ishaq menunjukkan bahwa huruf ma harus bermakna Istifhamiyah, sebab dalam riwayat tersebut terdapat kata مَاذً)

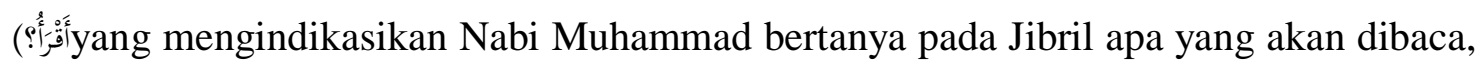
bukan menunjukkan Nabi Muhammad tidak bisa membaca.

\section{Simpulan}

Setelah diteliti ulang dapat dipetik sebuah hasil bahwa tulis menulis merupakan sebuah kebutuhan yang tidak bisa dipisahkan dari kehidupan orang Arab Jahiliyah. Dengan demikian, maka kehidupan sosial Nabi Muhammad sudah terbiasa dengan tulis menulis. Jika Nabi Muhammad dinyatakan sebagai Nabi yang tidak bisa membaca dan menulis, maka salah satu sifat wajib nabi tidak dimiliki oleh Nabi Muhammad. Demikian ini merupakan sebuah kemustahilan bagi Nabi Muhammad. Selain itu, hasil dari penelitian ini menunjukkan bahwah makna lafad al-Ummi yang ada dalam al-Qur'an bukan berarti tidak bisa membaca dan menulis, melainkan memiliki arti orang Arab atau orang yang tidak pernah membaca kitab suci sebelumnya.

36، Alwi al-Saqqaf, Takhrij Ahadits wa Atsar Kitab fi Dzilal al-Qur'an li Sayyid Quthub (Riyadh: Dar al-Hirjah, 1991), 25. 


\section{Daftar Pustaka}

'Alwi al-Saqqaf. Takhrij Ahadits wa Atsar Kitab fi Dzilal al-Qur'an li Sayyid Quthub. Riyadh: Dar al-Hirjah, 1991.

'Ali Abd al-Fattāh al-Maghrabì. al-Nubuwah wa al-Anbiya'fĩ al-Fikr al-Islämī. Kairo: Maktabah Wahbah. 1994. 16-34.

Aris Fauzan. Al-Nabi al-Ummiy dalam Telaah Historis-Semiotik. Jurnal Kajian Keislaman dan Kemasyarakatan, Vol. 3, No. 1, Juni, 2018.

Ahmad Hanif Fahruddin. Learning Society Arab Pra Islam (Analisis Historis dan Demografis). Jurnal Kuttab. Vol. 1, No. 1, Maret, 2017.

Ahmad bin Yahya bin Jabir. Futuh al-Buldan Kairo: Lajnah al-Bayan al-‘Arab, 1957.

Abd al-Malik bin Hisyam. al-Sirah al-Nabawiyah Mesir: al-Halaby. 1936.

Ahmad bin 'Ali al-Muqrizi. Imta' al-Asma' bi ma li al-Nabi min al-Ahwal wa al-Amwal wa al-Hafadah wa al-Mata'. Bairut: Dar al-Kutub al-'Ilmiyah. 1420.

Departemen Agama RI. Al-Qur'an dan Terjemahnya. Bandung: CV Diponegoro. 2008.

Dahrun Sarif. Pengaruh Alquran Terhadap Perkembangan Kaligrafi Arab. Jurnal Etnohistori. Vol. III, No. 2, 2016.

Eva Nugraha "Konsep al-Nabi al-Ummi dan Implikasinya dalam Penulisan Rasm" Refleksi Jurnal Ilmu-Ilmu Ushuludddin. Vol. 12, No. 2, 2011.

Ghanim Qaddawari al-Hamd. Rasm al-Mushhaf Dirasah Lughawiyah Tarikhiyah. Baghdad: Lajnah al-Wathaniyah. 1402.

Husain bin Muhammad al-Damaghani. Qamus al-Qur'an aw Ishlah al-Wujuh wa alNadzair fi al-Qur'an al-Karim. Bairut: Dar al-'Ilm li al-Malayin. 1980.

Israil Walifansun. Tarikh al-Lughat al-Samiyah. Mesir: Mathba'ah al-I’timad, 1348.

Isma'il bin 'Umar bin Katsir al-Qursyi. Tafsir al-Qur'an al- 'Adzim. Mesir: Dar al-Kutub al-Misr, t,t.

Jawwād 'Alì, al-Mufașsal fī Tärikh al- Arab Qabl al-Islām. Baghdād: Jāmi'ah Baghdād. 1993.

Muhammad bin Ismā‘îl al-Bukhārì. al-Saḥị̣ al-Bukhārī. Bairūt: Dar al-Ṭawuq al-Najāh, 1422.

Muhammad bin Ishaq bin Ya'qub. al-Fihrit li Ibn al-Nadim. Mesir: al-Maktabah alTijariyah, 1348.

Muhammad bin Muni' al-Zuhri. al-Thabaqat al-Kubra. Mesir: al-Maktabah al-Tijariyah. 1345. 
Muhammad Izzah Darwazah. al-Tafsir al-Hadits. Kairo: Dar al-Ihya' al-Kutub al'Arabiyah, 1383.

Muhammad bin Mukram bin Mandzur al-Afriqi al-Mashri. Lisān al- 'Arab. Kairo: Dar alMa'arif, 1990.

Mukmin. Konsep Keummian Nabi Muhammad dalam al-Qur'an (Tela'ah Kritis Terhadap Pemikiran Agus Mustofa dalam Perspektif Ilmu Balaghah) Proseding Konferensi Nasional Bahasa Arab III. Malang: Oktober, 2017.

Muhammad bin Isma'il bin Ibrahim bin Mughirah al-Bukhari. Jami' al-Musnad alSshahih al-Mukhtashar min 'Umur Rasulillah. Dar: Thauq al-Najah, 1422.

Raghib al-Ashfahani. al-Mufradat fi Gharib al-Qur'an. Bairut: Dar al-Ma'rifah, t.t.

R. H. Tamimi. Muhammad SAW dan Peletakan Dasar Peradaban Islam. Jurnal of Islam and Plurality, Vol. 3, No. 1, Juni, 2018.

Sulaiman bin Ahmad bin Ayyub al-Thabrani. al-Mu'jam al-Kabir. Bairut: Maktabah al'Ulum wa al-Hukm, 1404.

Yahya Wahib al-Jubairi al-Khath wa al-Kitabah fi al-Hadharah al-'Arabiyah. Bairut: Dar al-Gharb al-Islami, 1994. 